\title{
NÁVRH ZLOŽENIA ŤAŽKÉHO BETÓNU VO FUNKCII BIOLOGICKÉHO TIENENIA POMOCOU JADROVÝCH ELEMENTÁRNYCH ANALYTICKÝCH TECHNÍK
}

\author{
DESIGN OF HEAVYWEIGHT CONCRETE USED IN RADIATION \\ PROTECTION BY NUCLEAR ELEMENTAL ANALYTICAL TECHNIQUES
}

Janette Podhorská,,, Martin Tchingnabé Palou ${ }^{1}$

"janette.dragomirova@savba.sk

${ }^{1}$ Slovenská akadémia vied, Ústav stavebníctva a architektúry, Oddelenie hmôt a reológie, Dúbravská cesta 9, 845 03 Bratislava 45, Slovenská republika

\begin{abstract}
Abstrakt
Na základe predošlých výskumov v oblasti t’ažkých betónov boli pripravené vzorky za použitia dvoch t’ažkých kamenív s vysokou objemovou hmotnost'ou, portlandského cementu a SCMs. Analýza chemického zloženia plniva aj spojiva bola realizovaná pomocou troch metód a to NAA, PGAA a XRF. Z výsledkov fyzikálno-mechanických vlastností vzoriek je zrejmé, že vzorky po 28 dňoch dosiahli triedu pevnosti betónu C55/67. Hodnoty objemovej hmotnosti betónu sa zist'ovali v čerstvom aj v zatvrdnutom stave a značne presahujú $3000 \mathrm{~kg} \mathrm{~m}^{-3}$. Ostatné sledované vlastnosti preukazujú, že tieto betóny je možné oznat' za vysokopevnostné t'ažké betóny. Rovnako použité materiály preukázali dobré aktivačné vlastnosti.
\end{abstract}

\section{Kl'účová slová}

Ťažký betón, NAA, PGAA, XRF

\begin{abstract}
High compressive strength heavyweight concrete specimens were prepared using two types of high-density aggregates, Portland cement, and SCMs. Elemental composition of aggregates and cementitious materials were performed by NAA, PGAA, and XRF methods. The mechanical and physical properties confirm that these concretes meet the requirements of concrete strength grade $\mathrm{C} 55 / 67$ after 28 days of curing, which makes them considered High Compressive Strength Concretes. The fresh and dry density values far exceed $3,000 \mathrm{~kg} \mathrm{~m}^{-3}$. Other properties, tensile strength and modulus of elasticity provide basic evidence to support the idea that these concretes could be considered as High-Performance Heavyweight concretes. Also, the ingredients of the above concrete showed good activation properties.
\end{abstract}

\section{Keywords}

Heavyweight concrete, NAA, PGAA, XRF

\section{1 ÚVOD}

Pri navrhovaní t’ažkého betónu (HWC) pre funkciu biologického tieniaceho štítu proti ionizujúcemu žiareniu hlavne v jadrových elektrárňach, ale aj v zdravotníckych zariadeniach, urýchl'ovačoch častíc alebo skladovacích boxoch jadrových odpadov sa musí brat' do úvahy kompletné chemické zloženie t’ažkého kameniva a cementových materiálov nielen na báze XRF analýzy, ale aj výsledky analýzy pomocou neutrónovej aktivačnej analýzy (NAA) a metódy okamžitého gama-žiarenia aktivačnej analýzy (PGAA). Tieto metódy poskytujú kompletné znalosti o zložení elementárnych prvkov vrátane rádionuklidov, čo umožňuje predpovedat' aktivácie vzorky v jadrovom reaktore.

Ťažký betón zostáva zd'aleka najpoužívanejším materiálom na tienenie ionizujúcich žiarení z reaktorov vd'aka svojim konštrukčným vlastnostiam a dobre vyváženej zmesi l’ahkých a t'ažkých atómových jadier. Je teda účinný ako pri pohlcovaní gama žiarenia, tak aj pri spomal'ovaní rýchlych neutrónov elastickým a neelastickým rozptylom 
[1], [2], [3]. Lahké jadrá, najmä vodíkové jadrá, ktoré sú obsiahnuté v chemicky viazanej vode zhydratovaného betónu, tlmia rýchle neutróny v dôsledku vel'kého obsahu vodíka [4], [5], [6]. Agregáty obsahujúce kovových prvkov s vysokou atómovou hmotnost’ou sú účinné pri zoslabovaní gama žiarení. Navyše vysoká pevnost' t’ažkých betónov by mohla poskytnút' d'alšiu výhodu použitia betónovej konštrukcie na dosiahnutie požadovanej nosnosti v porovnaní s konvenčným betónom.

Ciel'om tejto štúdie bolo navrhnút' HWC, ktorý dokáže splnit’ požiadavky funkčných materiálov pre tienenie jadrových žiarení s preukázanou nízkou aktiváciou a vysokými mechanickými vlastnost’ami. Práve dôkladný návrh betónových zmesí a ich dávkovanie je pri výrobe t’ažkého betónu náročnejším procesom ako pri bežných betónových zmesiach [1], [2]. Výber materiálov podmienený horeuvedenými analýzami elementárneho zloženia suroviny umožňuje vopred stanovit’ aktivačné vlastnosti pripravovaného betónu. Následne výber materiálov aj s ohl'adom na požadované fyzikálno-mechanické vlastnosti HWC umožňuje výslednému betónu zastávat' dvojitú úlohu tieniacej funkcie a štrukturálnych vlastností požadovaných pre biologické tienenie. V tejto štúdii sa diskutuje vplyv druhu kameniva a zloženia spojiva s obsahom doplnkových cementových materiálov (SCMs) na objemovú hmotnost', pevnost' v tlaku a pevnost' v t’ahu betónu, navrhnutého betónu za pomoci výsledkov XRF, NAA a PGAA.

\section{METODIKA}

\section{Jadrové analytické metódy: NAA a PGAA}

Základom oboch metód je detekcia charakteristických gama lúčov, emitovaných z jadier zlúčenín ožiarením neutrónov. V prípade NAA ožarovanie a detekcia y-fotónov prebieha oddelené v priestore a čase. Pod pôsobením neutrónov dochádza ku vzniku rádioaktívneho nového (dcérskeho) jadra a radiačný záchyt (n, $\gamma$ ), z ktorého sú detegované iba rozpadové $\gamma$-fotóny. Pri aplikácii PGAA je aktivácia a detekcia y-fotónov súčasná a analytické signály zvyčajne pochádzajú z radiačného záchytu neutrónov s nižšou energiou.

NAA je značne výhodná pre určovanie stopových prvkov v rozsahu koncentrácií $\mu \mathrm{g} / \mathrm{g}$ alebo nižších, zatial’ čo PGAA je nedeštruktívna metóda na analýzu hlavných prvkov a niektorých stopových prvkov v úrovni $\mu \mathrm{g} / \mathrm{g}$, ktoré sa len t’ažko merajú inými metódami (napr. H, B, Cl, Gd) [7]. Merania NAA a PGAA sa uskutočnili vo výskumnom reaktore $\mathrm{v}$ Budapešti (BRR), zariadenia prevádzkuje Oddelenie jadrovej analýzy a rádiografie v priekopníckom Centre pre energetický výskum Mad’arskej akadémie vied. Metódy boli validované mnohými geologickými referenčnými materiálmi a štandardmi a medzi laboratórnym porovnaním [8], pričom obe metódy použili metódu štandardizácie k0. PGAA a tiež NAA vyžadujú iba jednoduchú prípravu vzorky. Priebeh týchto meraní bol publikovaný $\mathrm{v}[9]$.

\section{Charakteristika použitých materiálov a ich fyzikálne vlastnosti}

Stanovenie hustoty materiálov bolo realizované pomocou automatického plynového pyknometra Quantachrome Pentapyc 5200e. Meranie špecifického povrchu sa realizovalo pomocou analyzátora sorpcie plynov Autosorb iQ metódou BET. Výsledky sú uvedené v [10]. XRF analýza chemického znoženia je uvedená v [10].

Ako plnivá boli použité prírodné kamenivá baryt (SABAR, s.r.o., Markušovce, Slovensko) pre zmesi CONBA1 a CONMIX1-2 a magnetit (LKAB Minerals, Ltd., Luleå, Švédsko) pre zmesi CONMAG1 a CONMIX1-2. Zloženie kameniva v jednotlivých zmesiach je uvedené v [10]. Použité kamenivo bolo preosiate na jednotlivé štandardizované frakcie a ich opätovné premiešanie bola definovaná krivka zrnitosti s nominálnou maximálnou vel'kost'ou zrna kameniva 16 mm, ktorej dôkladný návrh zabezpečuje ideálne rozloženie zín kameniva v betóne. Krivka zrnitosti kameniva je uvedená v [11].

Ako spojivo bola použitá zmes portlandského cementu EXTRACEM CEM I 42,5 R (CRH Slovensko, a. s. Rohožník, Slovensko), vysokopecnej trosky-BFS (Kotouč Štramberk, spol. s r. o., Česká republika), metakaolinu - MK L05 Mefisto (České lupkové závody, a.s., Nové Strašecí, Česká republika) a kremičitého úletu - SF (Oravské ferozliatinárske závody, a. s., Istebné, Slovensko). Plastifikátor Stachement 2025(ST2025) (SP; hustota $1065 \mathrm{~kg} . \mathrm{m}^{-3}$, obsah sušiny $30 \pm 1,5 \%$ a hodnota $\mathrm{pH}$ 5,0-8,0) (STACHEMA Bratislava, a. s., Slovensko) bol primiešaný do zámesovej vody v množstve $0,6 \mathrm{~kg}$ na $100 \mathrm{~kg}$ cementu.

\section{Návrh zloženia vysokopevnostného t’ažkého betónu}

Pri aplikácii betónovej konštrukcie v jadrovom reaktore má vel'ký význam pomer a homogenita zloženia betónu vzhl'adom na jeho konštrukčnú stabilitu a tieniacu schopnost'. Navyše, prítomnost' niektorých izotopov v betóne pri určitom ožiarení, môže byt' nepriamym zdrojom jadrových žiarení. Z tohto dôvodu sa pri návrhu betónu berie do úvahy nielen jeho zloženie, ale aj prítomnost' rádioizotopov v jednotlivých zložkách s ohl'adom na ich 
rádioaktivačný potenciál po vystavení žiareniu. $\mathrm{Na}$ základe analýz použitých materiálov $\mathrm{v}$ tejto štúdii boli navrhnuté štyri typy t’ažkých betónov, ktoré sa líšili druhom kameniva a ich zmesou, zložením cementového spojiva a SCM. (Tab.1).

Tab. 1 Zloženie jednotlivých zmesí zmesi na $1 \mathrm{~m}^{3}$ [\%].

\begin{tabular}{|c|c|c|c|c|}
\hline & CONBA1 & CONMAG1 & CONMIX1 & CONMIX2 \\
\hline BA & 74,05 & - & 48,78 & 48,78 \\
\hline MAG & - & 77,94 & 26,26 & 26,26 \\
\hline CEM & 19,74 & 16,78 & 14,22 & 14,22 \\
\hline BFS & - & - & 2,85 & 2,85 \\
\hline SF & - & - & 0,95 & 0,95 \\
\hline MK & - & - & 0,95 & 0,95 \\
\hline SP & 0,12 & 0,10 & 0,13 & 0,13 \\
\hline $\mathbf{W}$ & 6,10 & 5,18 & 5,86 & 5,86 \\
\hline
\end{tabular}

\section{Postupy výroby vzoriek a metódy ich fyzikálno-mechanických meraní}

Miešanie čerstvého betónu sa uskutočňovalo v stavebnej miešačke (AGRO-WIKT BWA-150, 400 V). Čerstvá betónová zmes sa uložila do foriem s rozmermi 100 x 100 x $400 \mathrm{~mm}$, ktoré sa prikryli mokrými tkaninami a igelitom pre zabezpečenie zodpovedajúcej relatívnej vlhkosti pri tuhnutí vzoriek počas 7, 28, 90 a 180 dní.

Pevnost' v tlaku betónu sa zist'ovala na telesách s rozmermi 150x150x150 mm, d’alej uvádzaná ako $\mathrm{F}_{\mathrm{c}, \text { cube, }}$

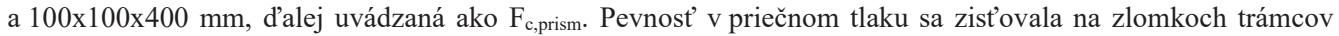
s podstavou 100x100x100 mm, d’alej uvádzaná ako $F_{c, l p}$ a pevnost' v t’ahu betónu sa zist'ovala na telesách s rozmermi 100x100x400 mm, d’alej uvádzaná ako $F_{c f}$. Skúšobné postupy boli uskutočnené podl'a európskej normy EN12390 1-7 v čase 7, 28, 90 a 180 dní. Statický modul pružnosti bol meraný na telesách s rozmermi 100x100x400 mm podl'a STN ISO 6784. Dynamický modul pružnosti bol meraný na rovnakých vzorkách pripravených na statický modul ultrazvukovou metódou pomocou zariadenia Ultrasonic Meter Matest. Modul pružnosti bol rovnako ako pevnostné charakteristiky meraný v čase 7, 28, 90 a 180 dní.

\section{VÝSLEDKY}

\section{Výsledky chemických analýz}

Zo skúmaných izotopov sú z hl'adiska aktivačných vlastností betónu najdôležitejšie tie s polčasom rozpadu kratším ako rok, avšak dlhším ako mesiac, ktoré v tomto prípade predstavujú nasledovné izotopy: ${ }^{141} \mathrm{Ce},{ }^{181} \mathrm{Hf},{ }^{59} \mathrm{Fe},{ }^{124} \mathrm{Sb}$, ${ }^{85} \mathrm{Sr},{ }^{160} \mathrm{~Tb},{ }^{46} \mathrm{Sc},{ }^{182} \mathrm{Ta},{ }^{65} \mathrm{Zn}$ a tiež tri izotopy s vel'mi dlhým polčasom rozpadu, ktoré môžeme označit' aj ako izotopy s dlhou životnost'ou, a to sú: $\left(\mathrm{T}_{1 / 2}\right):{ }^{134} \mathrm{Cs}\left(\mathrm{T}_{1 / 2}=2,07 \mathrm{r}\right),{ }^{60} \mathrm{Co}\left(\mathrm{T}_{1 / 2}=5,27 \mathrm{r}\right),{ }^{154} \mathrm{Eu}\left(\mathrm{T}_{1 / 2}=8,5 \mathrm{r}\right)$ a ${ }^{152} \mathrm{Eu}$ $\left(\mathrm{T}_{1 / 2}=13,5 \mathrm{r}\right)$.

Chemické zloženie cementu obsahuje z hl'adiska aktivačných vlastností zanedbatel'né množstvo izotopov s dlhou životnost'ou: ${ }^{134} \mathrm{Cs},{ }^{60} \mathrm{Co}{ }^{152} \mathrm{Eu} \mathrm{a}{ }^{154} \mathrm{Eu}$. Prvkov pozostávajúcich z izotopov s dlhým, ale menej ako ročným polčasom rozpadu je vo vzorke niekol'ko stoviek $\mu \mathrm{g} / \mathrm{g}$. Z nich treba brat' do úvahy najmä koncentráciu železa ${ }^{59} \mathrm{Fe}$ $\mathrm{S} \mathrm{T}_{1 / 2}=44,5$ dňa, ktorého je $\mathrm{v}$ použitom cemente $2,13 \% \mathrm{hm}$.

Chemické zloženie jednotlivých SCMs prekvapilo najmä zvýšeným obsahom všetkých troch rádioizotopov s dlhou životnost'ou v MK. Z tohto dôvodu bolo použitie MK ako náhrady cementu obmedzené na 5\%. Jeden z rádioizotopov s dlhou životnost'ou, konkrétne Eu, sa vyskytoval aj v BFS popri hlavných prvkoch $\mathrm{Si}, \mathrm{Al}, \mathrm{Ca}$ a Mg s nízkymi aktivačnými vlastnost’ami. Oproti obsahu v cemente je Eu v BFS obsiahnutý pät’násobne.

Chemická analýza barytového kameniva sa vykonala separátne pre frakcie 0/1, 1/2, 2/4, 4/8, 8/16 a plavený koncentrát barytovej rudy s vel'kost'ou 0,063/0,25, ktorý má vyšší obsah BaSO4. Baryt obsahuje hlavnú zložku Ba a S. Medzi d'alšie prvky možno zaradit' aj Fe a Mg (Obr. 1). Ako vedl'ajšie prvky bolo možné detegovat' Si, Ti, Al, Mn, Na, K a Sr. Všetky frakcie majú nízky obsah H (175-675 $\mu \mathrm{g} / \mathrm{g}), \mathrm{B}(2,3-28,5 \mu \mathrm{g} / \mathrm{g})$ a Cl $(21-222 \mu \mathrm{g} / \mathrm{g})$ meraný pomocou PGAA. Pomocou NAA boli detegované aj rádioizotopov s dlhou životnost'ou a to konkrétne Co v rozmedzí 5,4 a $6 \mu \mathrm{g} / \mathrm{g}$, avšak stále je to len polovica koncentrácie nameranej v použitom cemente (Obr. 2). Železa s relatívne dlhým polčasom rozpadu $\left(\mathrm{T}_{1 / 2}=44,5 \mathrm{~d}\right)$ je vo vzorkách okolo $20 \% \mathrm{hm}$. 


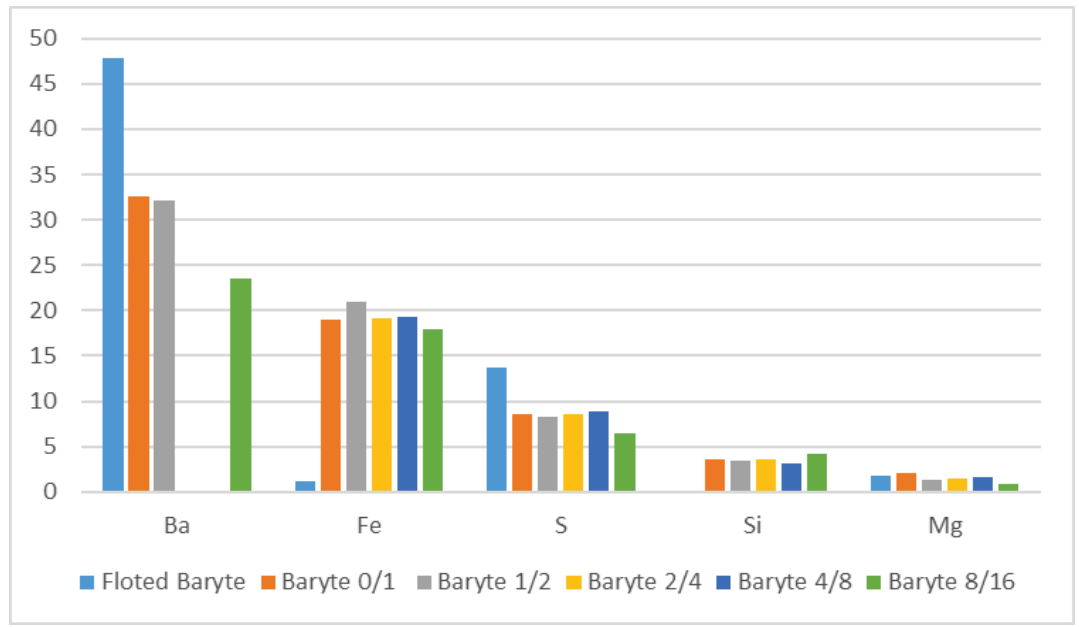

Obr. 1 Koncentrácia hlavných prvkov v BA [\% hm.].

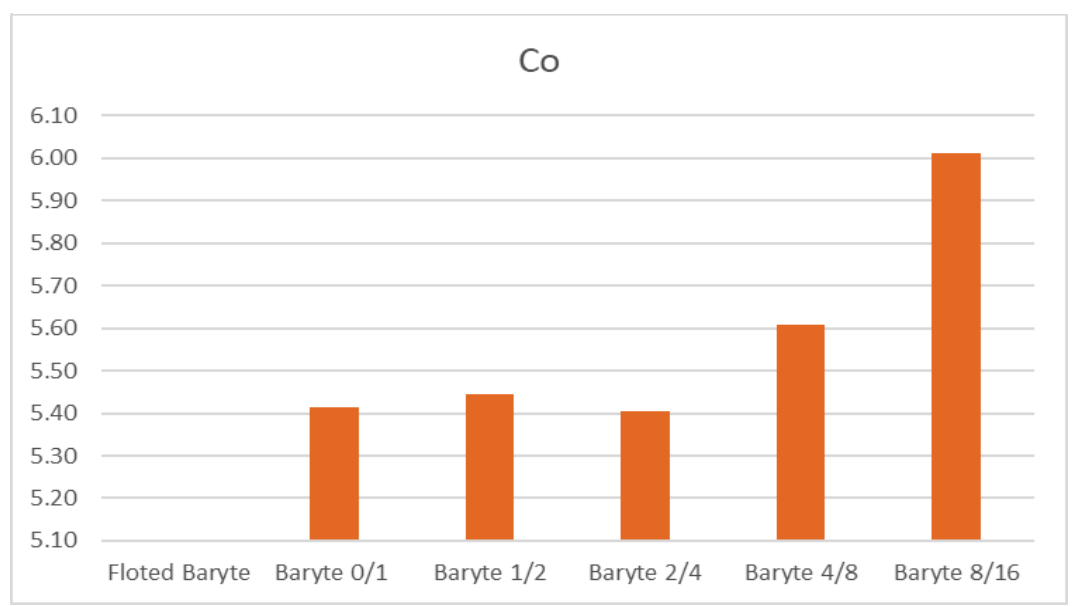

Obr. 2 Koncentrácia Co $[\mu \mathrm{g} / \mathrm{g}]$ vo vzorkách BA.

Ostatné prvky s $\mathrm{T}_{1 / 2}$ nižším ako rok, konkrétne $\mathrm{Sb}\left({ }^{124} \mathrm{Sb}-\mathrm{T}_{1 / 2}=60,2 \mathrm{~d}\right)$ je menej ako $500 \mu \mathrm{g} / \mathrm{g}$ a Sc $\left(46 \mathrm{Sc}-\mathrm{T}_{1}\right.$ $/_{2}=83,8$ d) sú nižšie ako $2,8 \mu \mathrm{g} / \mathrm{g}$. Elementárne zloženie barytového koncentrátu sa líši od ostatných frakcií, má zvýšený obsah $\mathrm{Ba}, \mathrm{S}$ a Sr, vykazuje znížené množstvo všetkých ostatných prvkov ale najmä rádioizotopov s dlhou životnost'ou Cs, Co, Eu, ktoré sú pod detekčným limitom NAA, zatial' čo obsah Fe je len okolo $1 \%$ hm. Neexistuje žiadna systematická zmena v koncentráciách prvkov s vel'kost’ou zín, s výnimkou obsahu Sb, ktorý sa zvyšuje so zvyšujúcou sa vel'kost'ou zisku vo vzorkách barytu.

Chemická analýza magnetitového kameniva bola rovnako ako v prípade barytového kameniva prevedená pre každú frakciu $(0 / 1,1 / 2,2 / 4,4 / 8,8 / 16)$ zvlášt'. Ako sa očakávalo, ich hlavným prvkom je Fe medzi 65-69 \% hm. (Obr. 3). Okrem Fe bolo možné vo všetkých vzorkách s PGAA merat' nízke množstvo Si, Ti, Mn, V, H, B, $\mathrm{Gd}$ a Cl. NAA poskytla údaje o koncentrácii stopových ale najmä rádioizotopov s dlhou životnost'ou. Koncentrácia Cs sa nachádza pod detekčným limitom, zatial' čo Eu je pod $1 \mu \mathrm{g} / \mathrm{g}$. Co má koncentráciu v rozmedzí 99-127 $\mu \mathrm{g} / \mathrm{g}$. (Obr. 4).

\section{Výsledky fyzikálno-mechanických vlastností betónov}

Mechanické vlastnosti vzoriek betónu sú uvedené na Obr. 5-8. Mechanické vlastnosti všetkých vzoriek betónu sa zvyšujú so zvyšujúcim sa časom ošetrenie. Z Obr. 6 a 7 je zrejmé že, pevnost' v tlaku a pevnost' v t'ahu vzoriek sa vyvíja vzhl'adom na typ kameniva použitého kameniva. Najvyššie pevnosti dosahuje CONMAG 1 a najnižšie CONBA 1. Pevnost' v tlaku všetkých vzoriek po 28 dňoch zodpovedá hodnote vysokopevnostného betónu [1]. 


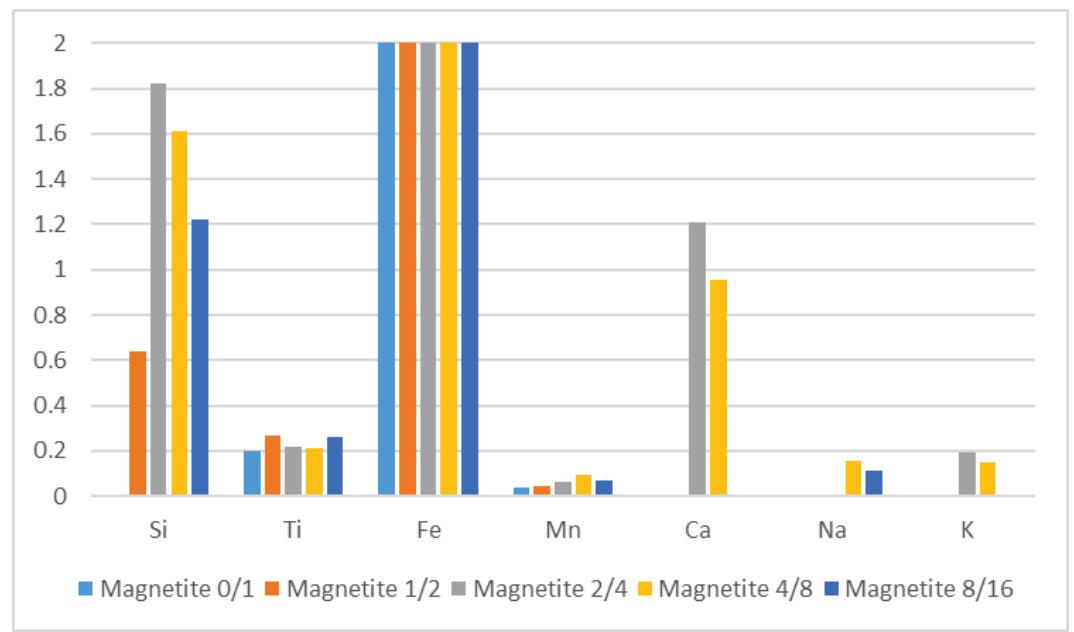

Obr. 3 Koncentrácia hlavných prvkov v MAG [\% hm.].

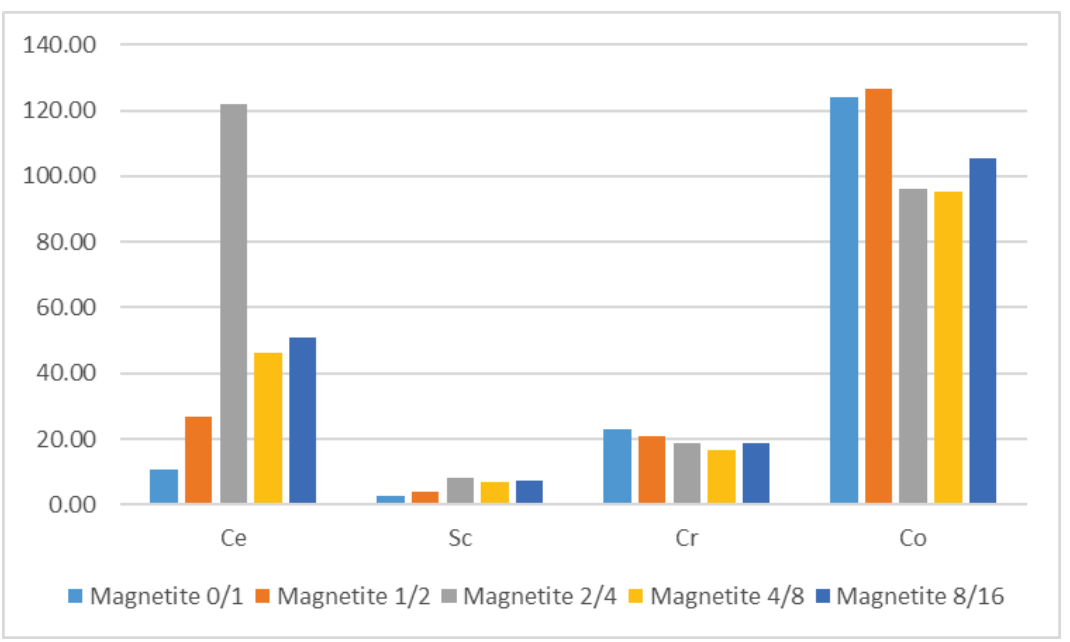

Obr. 4 Koncentrácia vedl’ajších prvkov v MAG $[\mu \mathrm{g} / \mathrm{g}]$.

CONMIX 1 a CONMIX 2 sú betóny vyrobené zo zmesí kameniva s čistým cementom alebo s cementom s pridaním SCMs. To umožňuje posúdit’ vplyv SCMs na mechanické a fyzikálne vlastnosti betónu. Tieto výsledky ukazujú, že použitie SCMs zlepšuje mechanické vlastnosti betónu vo všetkých obdobiach ošetrenia. SCMs hrajú $\mathrm{v}$ betóne dvojitú úlohu. Po prvé, pôsobia ako jemné plnivá vypĺn̆ajúce priestor medzi zrnami kameniva a cementovou pastou a po druhé sa podiel'ajú na chemickej reakcii prostredníctvom alkalickej aktivácie alebo puzolánovej reakcie a následnej tvorbe d’alších hydratačných produktov zodpovedných za zvýšenie pevnosti $\mathrm{v}$ tlaku [12].

Porovnaním hodnôt pevností v tlaku všetkých skúšok bolo preukázané, že tvar a rozmer skúšobného telesa neovplyvňujú hodnoty pevností v tlaku betónu tak výrazne, ako je to zvykom u bežného betónu s objemovou hmotnost'ou do $2600 \mathrm{~kg} \cdot \mathrm{m}^{-3}$. Tieto rozdiely sú značne znížené, a preto nie je možné použit' konvenčné výpočty na stanovenie vzt'ahu medzi kockovou, valcovou a hranolovou pevnost'ou v tlaku (Obr. 5).

Hodnoty objemovej hmotnosti vzoriek zatvrdnutého betónu CONBA 1 sú vyššie ako $3000 \mathrm{~kg} \mathrm{~m}^{-3}$, pre CONMAG 1 sú vyššie ako $3500 \mathrm{~kg} \mathrm{~m}^{-3}$ a pre CONMIX 1, CONMIX 2 sa pohybujú od 3286 do $3360 \mathrm{~kg} \mathrm{~m}^{-3}$ (Obr.7).

Najvyššiu objemovú hmotnost' dosahuje z pochopitel'ných dôvodov čerstvý betón tým, že je úplne nasýtený vodou. Tá sa časom spotrebováva na tvorbu hydratačných produktov v betóne a čast' sa odparuje. Následne s poklesom vody klesá aj objemová hmotnost'. Po 90 dňoch od výroby betónu, ked' už betón nepodlieha autogénnemu zmrašt'ovaniu $\mathrm{v}$ dôsledku vysychania betónu pri hydratácii, sú objemové zmeny $\mathrm{v}$ betóne podmienené len zmenami klimatických podmienok. 


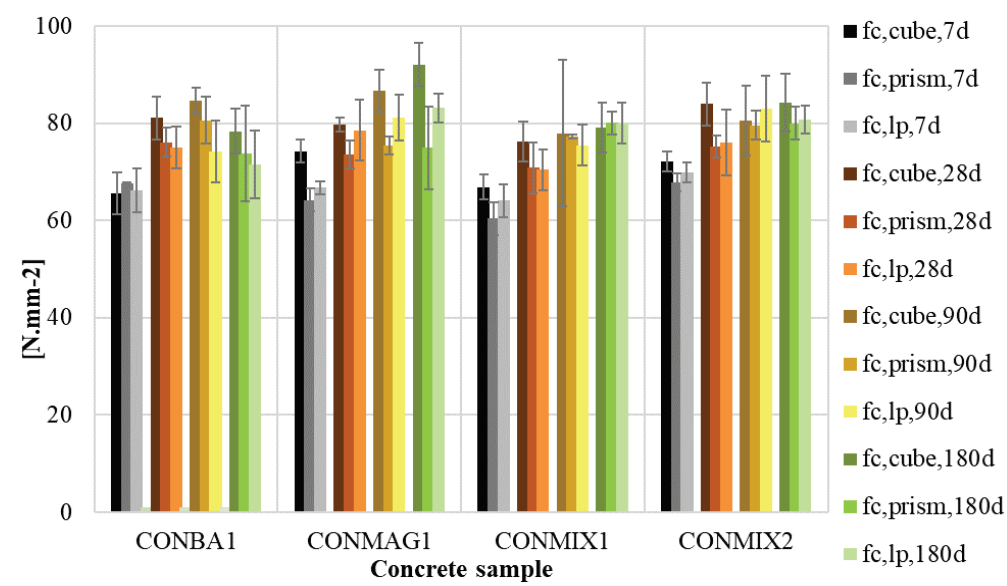

Obr. 5 Pevnost' v tlaku kocková $\mathrm{f}_{\mathrm{c}, \text { cube, }}$ hranolová $\mathrm{f}_{\mathrm{c}, \text { prism }}$ a pevnost' $\mathrm{v}$ priečnom tlaku betónu $\mathrm{f}_{\mathrm{c}} \mathrm{lp}\left[\mathrm{N} \mathrm{mm}^{-2}\right]$.

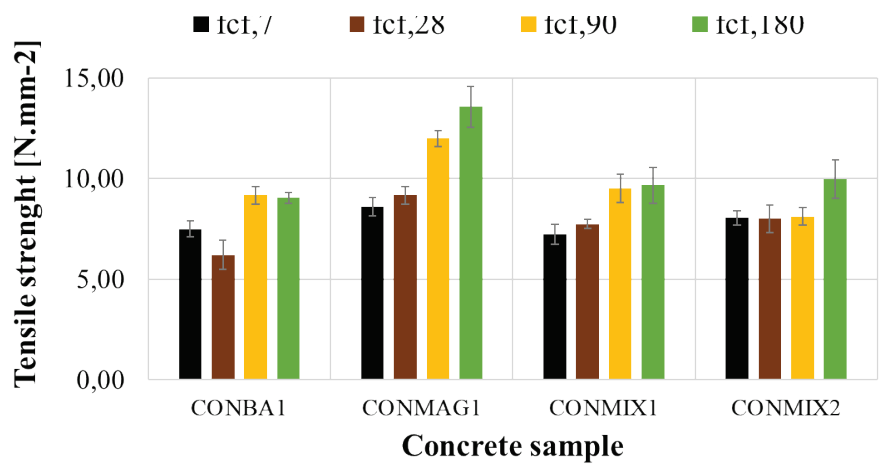

Obr. 6 Pevnost' v t’ahu betónu $\mathrm{f}_{\mathrm{c}, \mathrm{f}}\left[\mathrm{N} \mathrm{mm}^{-2}\right]$.

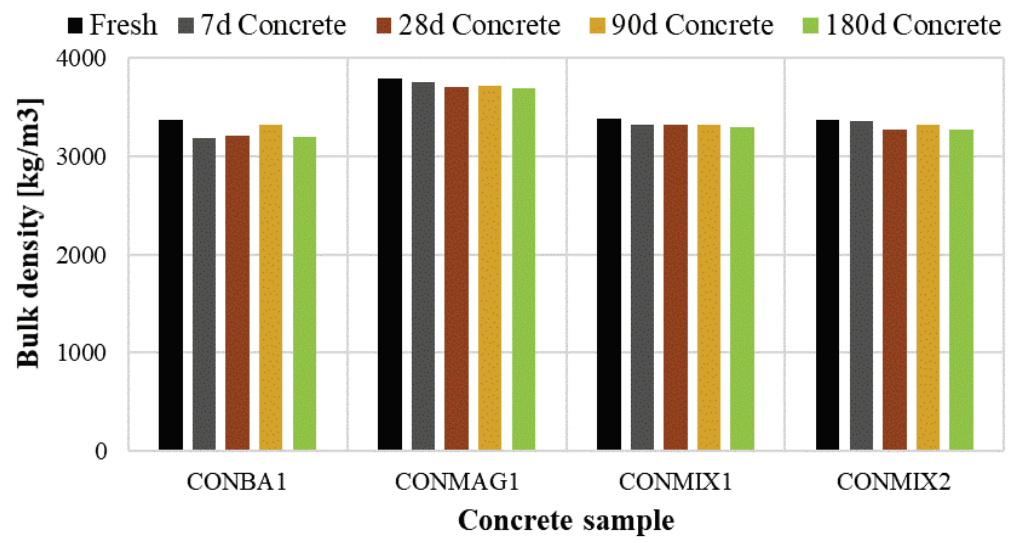

Obr. 7 Objemová hmotnost’ betónu $\left[\mathrm{kg} \mathrm{m}^{-3}\right]$.

Hodnoty statického a dynamického modulu pružnosti betónu v tlaku v závislosti od veku tvrdnutia sú znázornené na Obr. 8. S vekom betónu modul pružnosti v tlaku narastá a deformácia betónu sa znižuje [13]. 


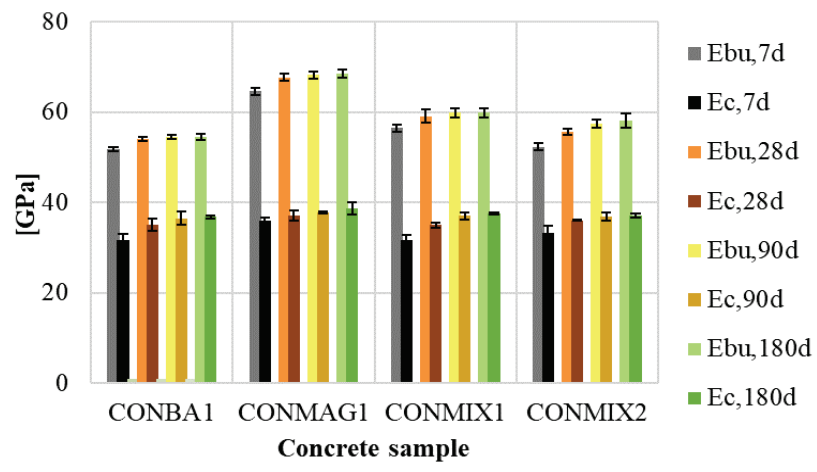

Obr. 8 Statický modul pružnosti betónu $\mathrm{E}_{\mathrm{c}}[\mathrm{GPa}]$ a dynamický modul pružnosti betónu $\mathrm{E}_{\mathrm{bu}}[\mathrm{GPa}]$.

\section{ZÁVER A DISKUSIA}

V tejto štúdii boli vytvorené štyri betónové zmesi spadajúce do triedy vysokopevnostných t’ažkých betónov. Na výrobu vzoriek bol použitý cementové kompozity a zmes kamenív barytu a magnetitu. Pri návrhu betónu boli zohl'adnené výsledky NAA a PGAA rádionuklidov na vyhodnotenie potenciálnych rizík pri použití týchto betónov ako biologického tienenia v jadrových elektrárňach a iných zariadeniach ale aj výsledky XRF. Výsledky ukázali, že tieto betóny pripravené z rôznych zložiek s rôznymi počiatočnými rádionuklidmi majú dobré aktivačné vlastnosti a spĺnajú požiadavky, ako je spracovatel'nost', pevnost' a trvanlivost' t'ažkého vysokopevnostného betónu. Všetky vzorky dosiahli vysoké objemové hmotnosti medzi 3190 kg.m ${ }^{-3}$ až 3710 kg.m ${ }^{-3}$ podl'a materiálového zloženia, vd'aka čomu ich možno považovat' za t’ažký betón. Taktiež mechanické vlastnosti (pevnost' $\mathrm{v}$ tlaku, pevnost' $\mathrm{v}$ priečnom tlaku, pevnost' t'ahu a modul pružnosti betónu) spíňajú predpoklady pre vysokopevnostné betóny.

\section{Pod'akovanie}

Táto práca bola súčast'ou projektov Agentúry na podporu výskumu a vývoja APVV-19-0490, APVV-15-0631 a Slovenskej grantovej agentúry VEGA č. 2/0032/21 a 2/0017/21.

\section{Použité zdroje}

[1] OUDA, Ahmed S. Development of high-performance heavy density concrete using different aggregates for gamma-ray shielding. Progress in Nuclear Energy. 2015, 2015(79), 48-55. ISSN 0149-1970. Dostupné Z: doi:https://doi.org/10.1016/j.pnucene.2014.11.009

[2] MOSTOFINEJAD, Davood, Mohammad REISI a A. SHIRANI. Mix design effective parameters on gamma-ray attenuation coefficient and strength of normal and heavyweight concrete. Construction and Building Materials. 2012, 2012(28), 224-229. ISSN 0950-0618. Dostupné z: doi:10.1016/j.conbuildmat.2011.08.043

[3] PARK, Kyoungsoo, Hyung-Tae KIM, Tae-Hyun KWON a Eunsoo CHOI. Effect of neutron irradiation on response of reinforced concrete members for nuclear power plants. Nuclear Engineering and Design: An International Journal devoted to all aspects of Nuclear Fission Energy. 2016, 2016(310), 15-26. ISSN 0029-5493. Dostupné z: doi:10.1016/j.nucengdes.2016.09.034

[4] POMARO, Beatrice, Fabiana GRAMEGNA, Roberto CHERUBINI, Viviana DE NADAL, Valentina A. SALOMONI a Flora FALESCHINI. Gamma-ray shielding properties of heavyweight concrete with Electric Arc Furnace slag as aggregate: An experimental and numerical study. Construction and Building Materials. 2018, 2018(200), 188-197. ISSN 0950-0618. Dostupné z: doi:10.1016/j.conbuildmat.2018.12.098

[5] LE PAPE, Yann. Structural Effects of Radiation-Induced Volumetric Expansion on Unreinforced Concrete Biological Shields. Nuclear Engineering and Design. North-Holland, 2015, 2015(295), 534 548. ISSN 0029-5493. Dostupné z: doi:https://doi.org/10.1016/j.nucengdes.2015.09.018

[6] MIRHOSSEINI, Somayehsadat, Maria Anna POLAK a Mahesh PANDEY. Nuclear radiation effect on the behavior of reinforced concrete elements. Nuclear Engineering and Design. 2014, 2014(269), 57- 
65. ISSN 0029-5493. Dostupné z: doi:10.1016/j.nucengdes.2013.08.007

[7] RÉVAY, TAMÁS BELGYA, Zsolt a Tamás BELGYA. Principles of the PGAA method. Handbook of Prompt Gamma Activation Analysis: with Neutron Beams. 1. Boston, MA: Springer-Verlag US 2004, 2004, s. 1-30. ISBN 978-0-387-23359-8.

[8] GMÉLING, Katalin, András SIMONITS, Ibolya SZIKLAI-LÁSZLÓ a Dénes PÁRKÁNYI. Comparative PGAA and NAA results of geological samples and standards. Journal of Radioanalytical and Nuclear Chemistry. 2014, 2014(300), 507-516. ISSN 0236-5731. Dostupné z: doi:10.1007/s10967-014-3032-2

[9] DRAGOMIROVÁ, Janette, Martin T. PALOU, Katalin GMÉLING, Ildikó HARSÁNYI a László SZENTMIKLÓSI, Veronika SZILÁGYI, ed. Design of heavyweight concrete used in radiation protection. In: OLEK, J., M.A GLINICKI a D. JOZWIAK-NIEDZWIEDZKA, ed., C.K.Y. LEUNG. Brittle Matrix Composites 12: Proceedings of the 12th International Symposium on Brittle Matrix Composites. Warsaw: Institute of Fundamental Technological Research, 2019a, s. 195-210. ISBN 978-83-65550-20-0. ISSN -.

[10] DRAGOMIROVÁ, Janette, Martin T. PALOU a Radoslav NOVOTNÝ. Effect of heavy aggregates on concrete shrinkage. In: DVOŘÁK, Karel a Dominik GAZDIČ, ed. Binders, Materials and Technologies in Modern Construction V: 17th International Conference Silicate Binders (ICBM 2018). Brno: Trans Tech Publications, 2019b, s. 44-49. ISBN 978-80-214-5567-2. ISSN -.

[11] DRAGOMIROVÁ, Janette, Martin T. PALOU, Eva KUZIELOVÁ, Matúš ŽEMLIČKA, Radoslav NOVOTNÝ a Katalin GMÉLING. Optimization of cementitious composite for heavyweight concrete preparation using conduction calorimetry. Journal of Thermal Analysis and Calorimetry. 2020, 2020(142), 255-266. ISSN 1572-8943. Dostupné z: doi:https://doi.org/10.1007/s10973-020-09530-0

[12] KUZIELOVÁ, Eva, Matúš ŽEMLIČKA, Eva BARTONIČKOVÁ a Martin T. PALOU. The correlation between porosity and mechanical properties of multicomponent systems consisting of Portland cement-slag-silica fume-metakaolin. Construction and Building Materials. 2017, 2017(135), 306314. ISSN 0950-0618. Dostupné z: doi:10.1016/j.conbuildmat.2016.12.105

[13] ŠEVČÍK, Patrik a Iveta NAJDENÁ. MODUL PRUŽNOSTI BETÓNU. Stavebnícka ročenka 2010.1. Bratislava: JAGA Group, 2009, s. 8-11. ISBN 978-80-8076-076-2. 